\title{
Geomaterials as construction aggregates: a state-of-the-art
}

\author{
Richard Prikryl ${ }^{1}$ \\ Published online: 22 November 2021 \\ (c) Springer-Verlag GmbH Germany, part of Springer Nature 2021
}

\section{Introduction}

Construction aggregates derived from primary resources either by crushing of sound rock masses (crushed stone aggregates) or from naturally occurring unbound clastic sediments (natural sand and gravel aggregates) make the most voluminous mineral raw material exploited by humans nowadays (Fookes 1991; Přikryl 2017). Extremely low perunit cost of the extracted raw material (Přikryl et al. 2016) makes aggregates highly sensitive to transport distance from a quarry to the construction site. According to this basic relationship, constructional aggregates quarries should be preferably located close to their markets-construction sites. Aggregates belong to the essential materials needed for the development and maintenance of the infrastructure and built environment of our civilization. They can also be considered as one of the critical materials securing standards of our well-being.

Various aspects of aggregates desire research interest from at least three research communities: geologists (including engineering geologists) who participate in the evaluation of aggregate deposits and quality of aggregates, civil engineers who utilize them, and environmental scientists who increasingly face the problems related to impacts of extensive aggregate exploitation. Lack of sound and detailed investigation of rock materials aimed as a source of construction aggregates (often consequence of apparent cheapness of the raw material and the products-constructional aggregate) can have serious consequences: both in terms of safety of the built environment and its durability (Fookes 1997; van Loon 2002). Necessity of premature maintenance or even replacement of deteriorating built structures inevitably involves substantial additional cost. Aggregates thus deserve much more attention from geologists than it was

Richard Přikryl

richard.prikryl@natur.cuni.cz

1 Institute of Geochemistry, Mineralogy and Mineral Resources, Faculty of Science, Charles University in Prague, Albertov 6, 12843 Prague, Czech Republic common in past decades (Prentice 1990; Bobrowsky 1998; McNally 1998; Primel and Tourenq 2000; Smith and Collis 2001; Lorenz and Gwosdz 2003; Bustillo Revuelta 2021). It is evident that geologists became to be more and more involved in the evaluation of causes of premature damage of civil engineering structures by using their standard toolsmicroscopy and related analytical techniques (Verhoef and Van de Wall 1998, French 1991; Ingham 2009, 2011, 2019; Poole and Sims 2016).

\section{World production of aggregates}

In contrast to other mineral raw materials for which yearly production statistics are fairly documented by national geological surveys even on the worldwide scale (e.g., Mineral Commodity Summaries by U.S. Geological Survey 2021, British Geological Survey Mineral Production Data - Brown et al. 2021), sound statistical data on the annual production of construction geomaterials in general, and specifically of aggregates, is available only for some countries and/ or continents (e.g., USA, European countries) (Kecojevic et al. 2004; Menegaki and Kaliampakos 2010). Overall availability and low per-unit cost are considered to be the main reasons for poor reporting of aggregate quarrying in mineral production statistics (Miatto et al. 2017).

Despite lack of comparable data on world-scale (Miatto et al. 2017), several sound estimates give evidence for recent annual (period of 2015-2020) demand for constructional aggregates ranging from 40 to $50 \mathrm{Gt}$ (e.g., Tam et al. 2018; O'Brien 2016). However, regional distribution of aggregate consumption is highly variable. At present, about half of aggregate demand occurs in China (some 15-20 Gt per year), making it the largest aggregate market in the world, followed by India (about 5.5 Gt per year) as the second largest one. These two most populated countries, along with some other highly populated, rapidly developing countries in Southeast Asia and Latin America, experience high demand for aggregates and other constructional geomaterials specifically due to very ambitious new infrastructural projects 
(Schandl and West 2010, 2012). As noted by Miatto et al. (2017), the growth pattern of material consumption in construction correlates more fairly with the increase in GDP than with the actual level of GDP in these countries.

Concerning the most developed countries (e.g., member states of EU, USA or Japan), typical aggregate demand ranging from 5 to $6 \mathrm{t}$ per capita and year are driven mainly by maintenance or rebuilding of existing infrastructure, although development of new infrastructure such as highspeed railways plays important role as well due to strict requirements on aggregate quality (Indraratna et al. 2011; Nurmikolu 2012; Zhang et al. 2019).

\section{Modes of aggregates end-use}

Concerning the mode of utilization, aggregates are principally used either in a bound state (concrete) or unbound. Aggregates make essential part of the most widely used constructional material—concrete, which is vital for many other purposes in transport-infrastructural, commercial—and residential building, and other building projects. In concrete, different size fractions of coarse and fine aggregates make up about $75-85 \%$ of its mass (Alexander and Mindess 2005). Therefore, considering recent annual production of cement worldwide (4-4.2 Gt), about half of aggregates (from the total of $40-50 \mathrm{Gt}$ ) is spent in the manufacturing of hydraulic cement concrete (similar estimates can be found elsewheresee e.g., Gagg 2014). Another 2 Gt of aggregates are bound by bitumens in asphaltic concrete (with typical mixing proportions $95 \%$ of aggregate and 5\% of bitumen) annually. The acceleration of aggregate consumption worldwide during the twentieth century can be thus linked with enormously increased consumption of concrete which replaced most of the traditional constructional geomaterials such as natural stone and/or bricks (Pries and Janszen 1995). Despite well-meant trials to make concrete utilization more environmentally friendly (Mehta 2002; Meyer 2009; Langer 2016; Sonebi et al. 2016), cement production and concrete utilization still range to human activities with the highest energetic and ecological footprints (Horvath 2004, Solís-Guzmán and Marrero 2015).

\section{Basic types of aggregates}

\section{Aggregates from primary resources}

Most of the construction aggregates (Table 1) still come from primary natural resources-natural sands and gravels, or crushed stone aggregates (Poulin et al. 1994; Smith and Collis 2001), although importance of secondary sources (industrial by-products or wastes, manufactured aggregates, construction and demolition wastes) is rapidly increasing (De Mulder 1984). Each type of aggregate has certain advantages but also many disadvantages (Table 2) which are not solely related to their properties and performance in use but also to other factors such as impact on the environment.

Even when considering primary sources of aggregates alone, crushed stone and sands cannot substitute each other in specific modes of utilization. For example, mortar design requires mostly natural sands from fluvial deposits due to favorable shape and morphology of sand particles. Shortage in supply of high-quality natural sands or their physical absence led to increased research in potential usage of crushed stone fine fractions either in mortars or in concrete as one of the most important so-called alternative fine aggregates (Kirthika et al. 2020). Crushed stone fines (specifically sizes below $0.063 \mathrm{~mm}$ in $0 / 4 \mathrm{~mm}$ fraction) are in oversupply (Guimaraes et al. 2007) with some limitations in application, therefore many modes of their alternative utilization were investigated during past decades including use in construction (Hameed and Sekar 2009; Manasseh 2010; Mundra et al. 2016), ceramic industry (Buruchenko et al. 2020), carbon sequestration (Rigopoulos et al. 2018), etc. To achieve desirable shape characteristics and particle size distribution, vertical shaft impacting accompanied with air classification allows for production of crushed stone fines equal to natural sand (Cepuritis et al. 2015). Partial replacement (up to 50\%) of natural sand by crushed stone fines do not deteriorate mechanical properties or durability of concrete in general (Westerholm et al. 2008; Çelik and Marar 1996; Jadhav and Kulkarni 2013), in some cases (up to 30\% replacement) it even improves them (Manguriu et al. 2013).

\section{Aggregates from alternative sources}

As aggregates should make "inert" filler specifically when used in a bound state in concrete, other materials can hardly be used as an alternative. However, recent quest for new sources of aggregates, fuelled by construction boom in Asia and by efforts for more sustainable utilization of available mineral resources, leads to intensive search for involvement of rubbish from demolished structures (so-called construction demolition waste, $\mathrm{CDW}$ ) or of some manufactured aggregates (such as expanded lightweight aggregate) that are also derived from processed natural raw materials.

Emerging shortages in supply of aggregates from primary resources might be, at least partly, solved by the use of alternative materials, generally considered as wastes or by-products. Waste generation is inevitable for most human activities; but instead of waste landfilling, it can be often upgraded and used as alternative resources. This specifically concerns wastes from construction activities (construction and demolition waste (CDW)), and from mining and mineral raw materials processing waste (MMPW). On a European 
Table 1 Construction aggregates' typology based on various properties (based mostly on Lorenz and Gwosdz 2003, partly also on McNally 1998, and own consideration of the author)

\begin{tabular}{|c|c|c|c|}
\hline \multirow{3}{*}{$\frac{\text { Property }}{\text { Origin }}$} & \multicolumn{2}{|c|}{ Subdivision of construction aggregate types } & \multirow{2}{*}{$\begin{array}{l}\text { Examples } \\
\text { Sands, gravels, sand/gravel }\end{array}$} \\
\hline & Primary (natural) & Natural sand/gravel & \\
\hline & & Crushed stone & Blasted and crushed rock masses \\
\hline & Manufactured (synthetic, secondary) & $\begin{array}{l}\text { Lightweight based on various mineral } \\
\text { raw materials }\end{array}$ & $\begin{array}{l}\text { Bloating clay/claystones, vermiculite, } \\
\text { perlite }\end{array}$ \\
\hline & & $\begin{array}{l}\text { By-products/wastes from various } \\
\text { industrial processes }\end{array}$ & $\begin{array}{l}\text { Coal combustion products (fly ash, bottom } \\
\text { ash, boiler slag), slags from iron-ore } \\
\text { metallurgy, etc }\end{array}$ \\
\hline & & Construction and demolition waste & $\begin{array}{l}\text { Crushed concrete, crushed bricks, crushed } \\
\text { construction rubbish }\end{array}$ \\
\hline \multirow[t]{3}{*}{ Bulk density } & \multicolumn{2}{|c|}{ Lightweight (porous) (less than $2000 \mathrm{~kg} / \mathrm{m}^{3}$ ) } & $\begin{array}{l}\text { Natural lightweight (pumice, scoria, volcanic } \\
\text { ash, diatomite), expanded manufactured } \\
\text { (clays, claystones, and schists, expanded } \\
\text { vermiculite, expanded perlite), foamed } \\
\text { by-products/wastes (foamed blast furnace } \\
\text { slags, foamed glass) }\end{array}$ \\
\hline & \multicolumn{2}{|c|}{ Normal-weight (common dense) $\left(2000-3000 \mathrm{~kg} / \mathrm{m}^{3}\right)$} & Most of the rock types \\
\hline & \multicolumn{2}{|c|}{ Heavy-weight (high density) (above $3000 \mathrm{~kg} / \mathrm{m}^{3}$ ) } & $\begin{array}{l}\text { Some high-density (ultra)basic rocks, } \\
\text { barite, magnetite }\end{array}$ \\
\hline \multirow[t]{4}{*}{ Grain size } & \multicolumn{2}{|l|}{ ultrafine (less than $0.125 \mathrm{~mm}$ ) } & $\begin{array}{l}\text { Filler (rock flour, } D_{\max } 0.09 \mathrm{~mm} \text { ), } \\
\text { settleable fines }\left(D_{\max } 0.063 \mathrm{~mm}\right)\end{array}$ \\
\hline & \multicolumn{2}{|l|}{ fine (less than $4 \mathrm{~mm}$ ) } & Screened factions $0 / 2,0 / 4$ \\
\hline & \multicolumn{2}{|l|}{ coarse (above $4 \mathrm{~mm}$ ) } & Screened factions $4 / 8,8 / 16,32 / 63$ \\
\hline & \multicolumn{2}{|l|}{ Aggregate mixture (from 0 up to $125 \mathrm{~mm}$ ) } & Screened factions $0 / 16,0 / 22,0 / 32,0 / 90$ \\
\hline \multirow[t]{2}{*}{ Fraction $\mathrm{d} / \mathrm{D}$} & \multicolumn{2}{|l|}{ Narrow (D/d close to 2$)$} & $\begin{array}{l}\text { Screened factions } 2 / 4,4 / 8,8 / 16,16 / 32 \text {, } \\
32 / 63\end{array}$ \\
\hline & \multicolumn{2}{|l|}{ Wide (D/d above 2) } & Screened factions $4 / 11,4 / 32,8 / 32$ \\
\hline
\end{tabular}

level alone, these two categories of wastes contribute to more than $60 \%$ of total waste generated. Moreover, most of CDW and part of MMPW can be considered as inert, thus suitable for further use after appropriate processing.

Possible use of CDW as an alternative source of aggregates received enormous attention during past decades (Wilburn and Goonan 1998; Oikonomou 2005; Huang et al. 2007; Malešev et al. 2010; De Brito and Saikia 2012; Silva et al. 2014; Kabir et al. 2016; Cardoso et al. 2016; Akhtar and Sarmah 2018) as it makes the largest waste category. Despite numerous promising results, some uncertainties still remain. These concern specifically the fact that the employment of CDW aggregates in heavy duty applications is still not solved due to many constraints which make CDW aggregates less suitable than the primary aggregates.

\section{Production chain of aggregates}

Utilization of primary aggregates is linked with local geology and market (Poulin et al. 1994). While market is primarily influenced by construction activities within the frame of human civilization (anthroposphere), generation of aggregates is vitally linked with geology (i.e., any deposit of either natural sand/gravel or rock mass suitable for crushed stone resulted from genetic processes within lithosphere as a part of geosphere).

Location of an aggregate quarry is generally required close to the site of consumption (or to the market area), making one of typical features of this low cost ex-work material. The availability of specific types of aggregates in the region of consumption is thus primarily driven by local geology as transports over larger distances are economically unfavorable, specifically when considering road and/or railway.

Specifically, before WW2, aggregate quarries were opened whenever the raw material was required. However, rationalization of the construction industry with still growing necessity to use material of certain "standard" quality led to the concentration of quarrying and to the decrease of number of quarries with much larger production. To make opening an aggregate quarry a successful project, several important criteria must be fulfilled such as: proved quality and quantity of raw material, sufficient volume of extractable reserves, and reduction of potential environmental impacts and/or social conflicts from mining operation (Langer 1988). Reduction of number of aggregate quarries and increasing volumes extracted from remaining during post- $2 \mathrm{WW}$ period lead to the emergence of the mega- and 
superquarry concepts (Maltz 1994; Barton 1996; Black 1996). These large quarries are preferably planned in less inhabited coastal areas, being thus linked with another trend in constructional aggregate industry-internalization or globalization of stone production and its trade (Cowell 2000; Bendixen et al. 2021). International transport of aggregates is promoted by several factors such as geological one (physical lack of suitable aggregates or presence of aggregates of poor quality), societal/environmental (permitting problems related to mining licenses, etc.), or logistical/economical (interstate land shipping is often much more expensive than international sea transport) (Langer 1995).

Prevalence of sand and gravel production over crushed stone is another typical characteristic of past aggregate industry in many developed countries regardless of their local geological conditions (Fig. 1). This might be partly affected by apparently lower energetic demand on unit production from natural sand/gravel deposits compared to crushed stone. However, increasing global demand for construction aggregates, developments/requirements of modern concrete technology, and accelerated impact on ecosystems related to extraction of sand/gravel aggregates either along rivers or in marine environments resulted in a questioning the intensity of natural sand and gravel production (Gavriletea 2017; Torres et al. 2021 and references therein). However, it should be noted that despite declining production/consumption of natural sand/gravel aggregates in many developed countries, the same materials still are still largely produced in many less developed regions of the world (Goswami 1984a; Erskine et al. 1985; Hamad et al. 1996; Al-Harthi and Abo-Saada 1997; Al-Harthi and Amin 1999; Drew et al. 2002; Padmalal et al. 2008; Ako et al. 2014; Brunier et al. 2014).

Local conditions of a deposit are also crucial: presence of larger amounts of impurities (such as mineralized fault zones in rock masses or clay-rich beds in sedimentary deposits make utilization of the deposit more difficult due necessity of selective mining or increased processing expenses (Hamad et al. 2000; Räisänen and Torppa 2005; Engidasew and Barbieri 2014; Bahrami et al. 2015; Afolagboye et al. 2016; Vignaroli et al. 2017). Rock masses with complex weathering characteristics or containing hazardous minerals such as asbestos require special attention during exploration and testing of aggregate properties (Stubbs and Smith 1997; Vignaroli et al. 2013). Modern techniques allowing quick evaluation of exploratory, technical and regional planning data such as Geographic Information System (GIS), Decision Support Systems (DSS) or probabilistic prediction models are of great help in selection of new quarrying sites (Langer et al. 2002; Robinson and Kapo 2004; Robinson et al. 2004; Robinson and Larkins 2007; Karakaş 2014; Barakat et al. 2015, 2016). This means that genesis of the deposit of construction aggregates and its specific conditions are fundamental primary factors which 
Fig. 1 Trends in the production of primary constructional aggregates in the Czech Republic during the past 50 years show two important features: (1) significant drop in primary aggregate production due to the change of economy at the end of 1980 s, and (2) a clear switch to the prevalence of crushed stone over natural sands and gravels during last two decades. Own graphics based on mineral raw production data from the Czech Geological Survey

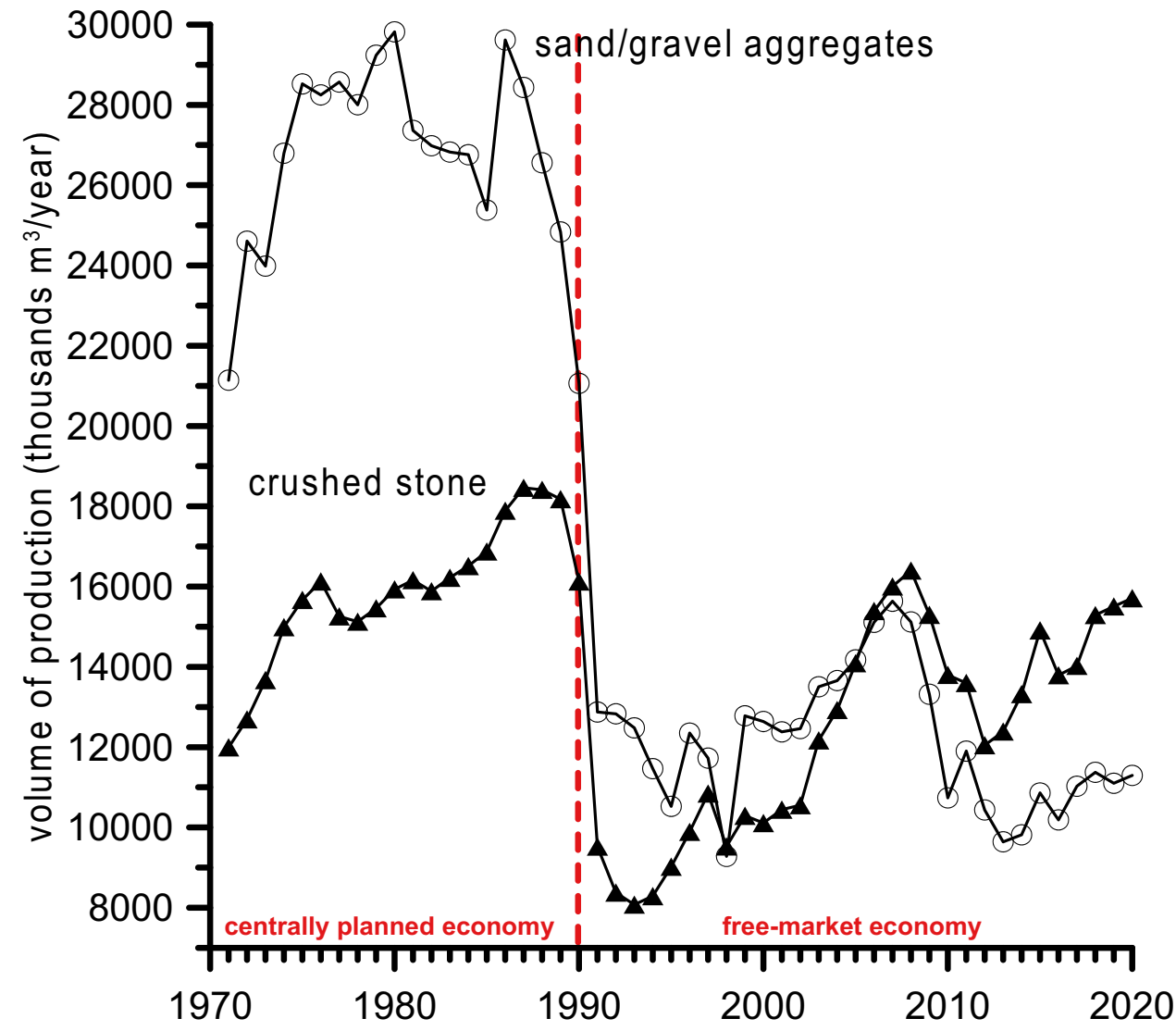

must be reflected even during exploration for new resources (Smith and Collis 2001).

Construction aggregates are obtained either by blasting, crushing and screening of solid rock masses (bedrock)the so-called crushed aggregate, or from excavated unbound sediments - naturally occurring sands and gravels. Most of the operations for aggregates are traditional surficial (openair) from hard-rock quarries or sand-pits; however, various environmental concerns related to the impact of these surficial operations can make underground extraction of hardrock aggregates and economically viable alternative (Stocks 1979, Lee and White 1993, Benardos et al. 2001, Millar et al. 2012).

\section{Properties}

Any construction material must possess certain properties to ensure stability and durability of the structure built out of it. Among the generalized quality requirements, aggregates' "soundness" is of utmost importance (Fookes 1980, 1997; Fookes and Walker 2011, 2012). It refers to the ability of aggregate source rock to withstand destructive forces from various environmental conditions (such as cyclic changes of water content, freezing/thawing, salt crystallization, temperature changes, etc.) and from various types of mechanical loads related to prevalent modes of end-use. Soundness of aggregates also refers to unwanted chemical reactions of source rock mineral constituents (e.g., oxidation of sulphide ore minerals, presence of reactive forms of silica); therefore, it can be considered as a synonym to durability sensu lato, similar to durability concept used in natural stone studies (Přikryl 2013).

Properties of construction aggregates are tested by various test methods, which partly differ from the testing of fundamental physical properties. Tests for the assessment aggregates' quality are often based on empirical approaches and prevalent modes of use. The principal categories of aggregate properties can be listed as:

- Mineralogical and petrographic description

- Geometrical characteristics

- Physical properties

- Mechanical performance

- Resistance to weathering, decay and deleterious chemical reactions.

As quality of aggregates is primarily governed by compositional and genetic factors of aggregate source rocks, focus on the characterization of mineralogical composition and 
detailed petrographic description of these rock masses is fundamental for correct interpretation of other technological tests and for understanding of their durability (Ramsay 1965; Hartley 1974; Ramsay et al. 1974; Kazi and Al-Mansour 1980b; Brattli 1992; Irfan 1994; Korkanç and Tuğrul 2004; Räisänen and Mertamo 2004; Räisänen and Torppa 2005; Al-Oraimi et al. 2006; Kılıç et al. 2008; Hofer et al. 2013; Naeem et al. 2014; Tuncay et al. 2016; Krutilová and Přikryl 2017; Ajalloeian and Kamani 2019). Due to the low cost of extracted material, mineralogical-petrographic study often achieves little attention in exploration and/or exploitation, but it becomes extremely important if some deterioration problems are encountered in structures built of certain types of aggregates showing greater vulnerability to various decay mechanisms (Miskovsky 2004; Miskovsky et al. 2004; Koukis et al. 2007; Loorents et al. 2007; Johansson et al. 2009; Loorents and Kondelchuk 2009; Tuğrul and Y1lmaz 2012; Hasdemir et al. 2016). During past decades, mineralogical-petrographic characterization of aggregates highly benefited from the adoption of quantitative analyses of rock microstructures by computer-assisted image analyses (Přikryl 2001, 2006; Åkesson et al. 2003) and from the increased interest of the detailed study of rock microfabrics and/or decay characteristics of aggregates source rocks and their influence on technological properties of produced aggregates (Shakoor et al. 1982; Goswami 1984b; Akpokodje and Hudec 1994; Brattli 1994; Kühnel et al. 1994; Tuğrul and Zarif 1999; Räisänen et al. 2003, 2005; Persson and Göransson 2005; Pomonis et al. 2007; Rigopoulos et al. 2010, 2012, 2013, 2014; Ündül and Tuğrul 2012; Diamantis et al. 2014).

When utilized in concrete (about half of current production of aggregates), compositional aspects of aggregate source rocks are of utmost importance specifically due to unwanted deleterious reactions of certain mineral phases in highly alkaline environments (e.g., Fookes 1980). This can initiate the so-called alkali aggregate reaction (AAR) and its counterpart-alkali silica reaction (ASR) which are amongst the most widely investigated phenomena of aggregates nowadays (Fournier and Bérubé 2000). Although the basic principles of these reactions have been well-understood during recent decades (Broekmans 2012; Lindgård et al. 2012), the extreme variability of aggregate composition and of local conditions of concrete exposure to specific environments still desire extensive research. Full understanding of these reactions is impossible without the development of new laboratory techniques which would allow for better recognition of changes such as physical properties of aggregates exhibiting various degrees of reactivity.

Size and shape of fragments are two basic geometric parameters that influence quality of aggregates for most of their uses (Turk and Dearman 1988; Barksdale et al. 1991; Rao and Prasad 2004; Chen et al. 2005; Uthus et al. 2007;
Ganapati and Adiseshu 2013; Xirouchakis 2013). Shape of crushed stone particles is governed by the rock micro- and macrofabric, and by processing - crushing (Bouquety et al. 2007). It is well known that particles with elongated shape are less mechanically resistant (Lees 1964; Lees \& Kennedy 1975; Ramsay et al. 1974). Similar to mineralogicalpetrographic studies, research interest focused on the potential of shape characterization by image analysis (Fernlund 1998, 2005a, b, c; Mora et al. 1998; Persson 1998; Wang 1999; Rao et al. 2002; Chandan et al. 2004; Maerz 2004; Erdogan et al. 2006; Al-Rousan et al. 2007; Fernlund et al. 2007; Arasan et al. 2010; Profitis et al. 2012) and on the adoption of automatic image analysis during aggregate production (Brzezicki and Kasperkiewicz 1999). Aggregate particle shape measurement (Fig. 2) by means of image analysis provides a set of precise data which can be easily evaluated by conventionally used shape-rating charts (Fig. 3). Image analyses of aggregate particles also allow for precise determination of specific shape parameters such as angularity or surface roughness (Masad et al. 2000; Mora and Kwan 2000). Use of advanced techniques of data processing such as fractals increases our understanding of particle geometry and surface roughness ( $\mathrm{Li}$ et al. 1993). Advanced imaging of particle shapes by X-ray CT techniques presents another promising direction in visualization of complex 3D shapes of aggregate particles (Garboczi 2002; Masad et al. 2005). Image analysis of the shape of aggregate particles is also very useful in the evaluation of various laboratory tests on aggregate mechanical performance (Guo et al. 2018).

Aggregate mechanical properties are essential in many applications either in unbound state - used as, e.g., railway ballast (Ferestade et al. 2017) or in bound state-e.g., in concrete (Beushausen and Dittmer 2015). Aggregate particles are exposed to various mechanical loads when used, e.g., in railway construction (cyclic crushing and attrition) and/or road surfacing aggregates (abrasion, polishing and/or attrition) (Paige-Green 2007; Descantes and Hamard 2015; Đokić et al. 2015; Palassi and Danesh 2015; Török 2015; Czinder and Török 2017). As these loads represent combinations of several forces, it is hard to predict the mechanical performance of aggregates from a single standardized rock mechanical test such as uniaxial compression or tension. Various empirical tests on mechanical performance of aggregates (e.g., Los Angeles Attrition Value (LAAV), microDeval test, Aggregate Crushing Value (ACV), Aggregate Impact Value (AIC), etc.; for details of these test compare reference textbooks such as Smith and Collis 2001) simulate combination of several mechanical loads (see Fig. 4) which are not identical to laboratory testing of rock mechanical properties as one of the fundamental physical properties (Erichsen et al. 2011).

It is thus not surprising that previously published research papers report quite variable correlation between 

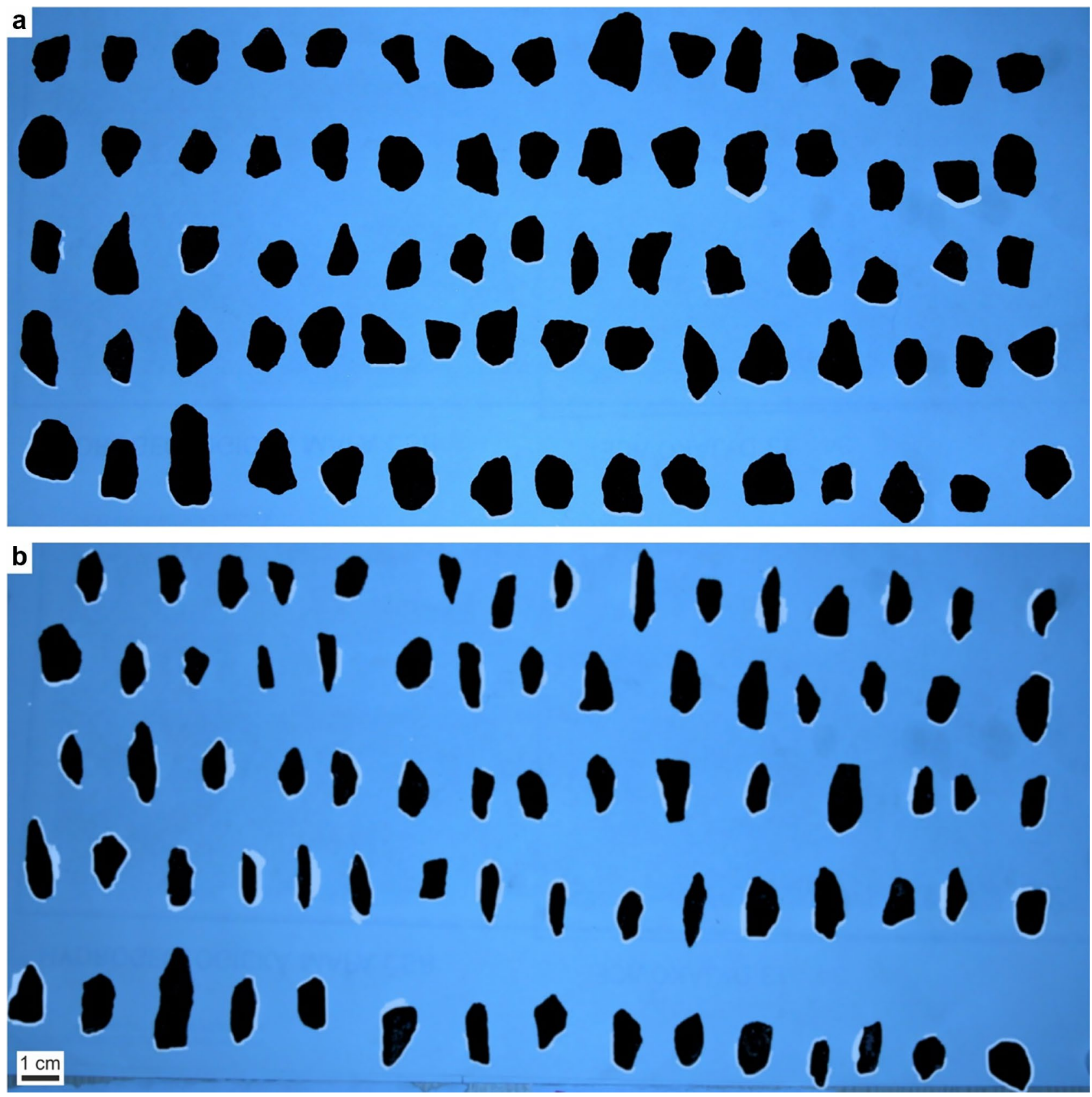

Fig. 2 Photographs of crushed stone particles (Palaeozoic greywacke) arranged in longest-intermedium position (a) and longest-shortest position (b) make basis for particle shape processing by image analy-

mechanical performance of aggregates and rock mechanical characteristics of their source rocks. Some authors claim sound inverse relationship between LAAV and uniaxial compressive strength (Ballivy and Dayre 1984; Cargill and Shakoor 1990; West 1994; Kahraman and Fener 2007; Ugur et al. 2010; Ozcelik 2011; Czinder et al. 2021). According to other studies (Kazi and AlMansour 1980a; Shakoor and Brown 1996; Al-Harthi 2001; Kahraman and Gunaydin 2007; Kahraman and sis software and for plotting the results into particle-shape rating diagram (see next Fig. 3, author's own data)

Toraman 2008; Kahraman and Fener 2008; Ugur et al. 2010; Jamil and Khan 2014; Afolagboye et al. 2017; Capik and Yilmaz 2017; Török and Czinder 2017; Esfahani et al. 2019; Teymen 2019; Abdelhedi et al. 2020), mechanical performance of aggregates can be even predicted from some indirect mechanical tests (e.g., Schmidt rebound hardness, dynamic elastic properties, crushability tests) which are more easily to be performed compared to compressive strength determination. However, several 
Fig. 3 Results of the shape analysis of crushed stone particles shown in previous Fig. 2 (Palaeozoic greywacke) documenting prevalence of platy to platy/ elongated particles, which shape can be at least partly explained by presence of sedimentary bedding of the source rock (author's own data)

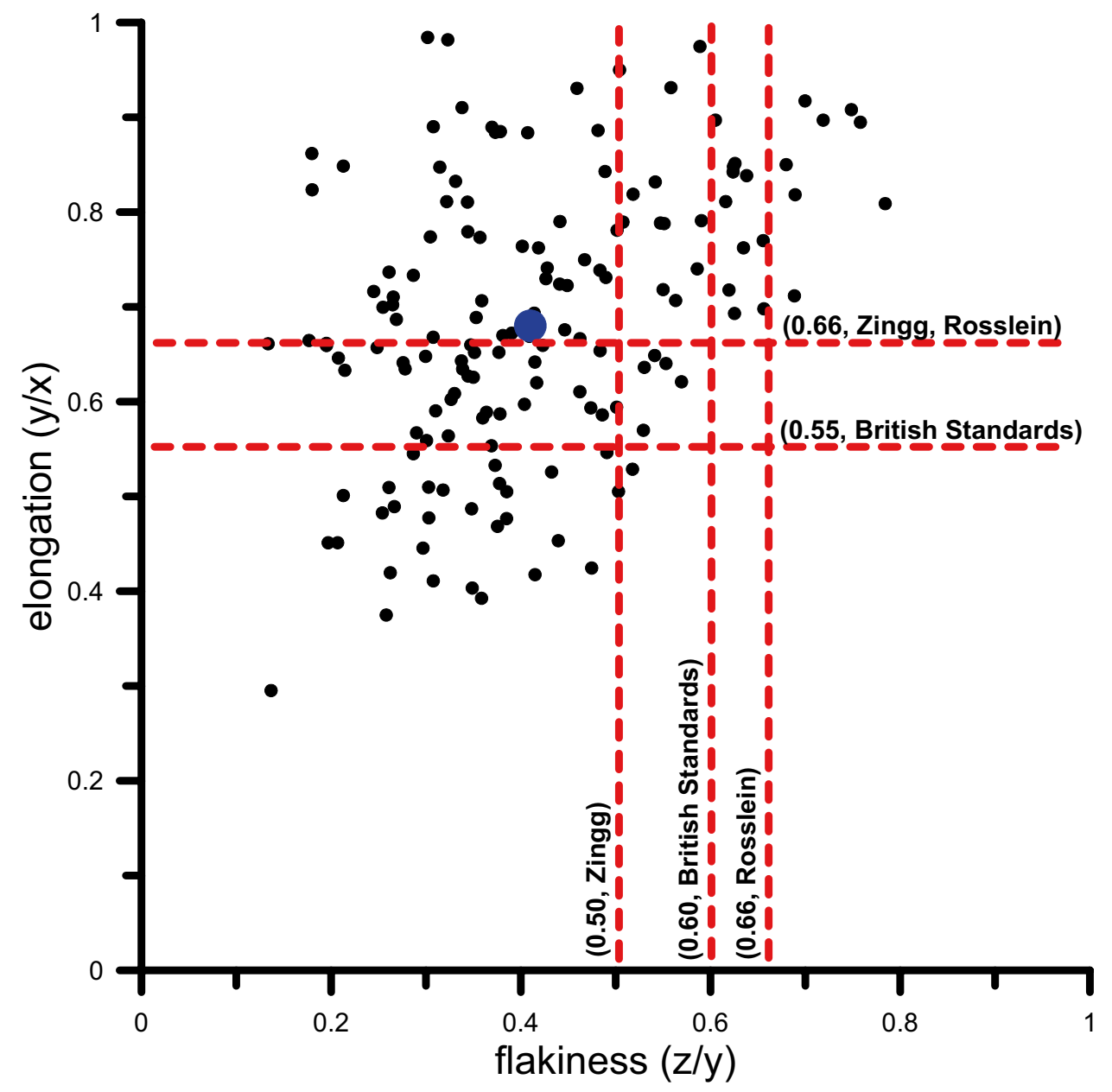

studies pointed out that some other rock properties such as grain size, degree of cementation and or porosity must be considered as well (Kazi and Al-Mansour 1980b; Ballivy and Dayre 1984), which might explain which some petrographic or genetic varieties provided much better correlation between LAAV and UCS than the others (Kasim and Shakoor 1996). To make experimental studies on relationships between mechanical performance of aggregates and rock mechanical characteristics of their source rocks more reliable, it is evident that researchers should focus also on deformational characteristics and energetic aspects of stress-strain behavior of these rocks which were ignored in previous studies.

Another source of uncertainty in often unclear correlation between fundamental mechanical properties (rock mechanical properties) and mechanical performance of aggregates can be found in the test design and specifically in reporting of test results. It has been found that rather than reporting a single number (i.e., percentage of fines produced from the original size fraction), a tri-plot reporting (composed of residue of the original size fraction, intermediate size fraction, and fine fraction) more faithfully reflects the real behaviour of aggregate during testing and shows better correlation to other properties (Ramsay 1965; Ramsay et al. 1977; Erichsen 2015).

\section{Criticality and sustainability of aggregates}

As in the case of other, more precious mineral raw materials, the recent debate opened a question of aggregate's criticality quite recently, trying to find a kind of consensus between rapidly growing urban areas which consume the largest volumes of construction materials (Campbell and Roberts 2003; Hofmann et al. 2009; Fry 2011; Tuğrul et al. 2016), but which natural resources are declining or are physically not available any more. Criticality of natural resources has started to be used as a concept on how to express risks of non-availability of materials vital for development or functioning of the society (Rosenau-Tornow et al. 2009; Graedel et al. 2012; Jin et al. 2016). In its general concept, criticality of any mineral raw material can be expressed by 2- or 3-components rating system, evaluating supply risk, vulnerability to supply restrictions, and environmental implications. Supply risk (both medium- and long-term) provides a 

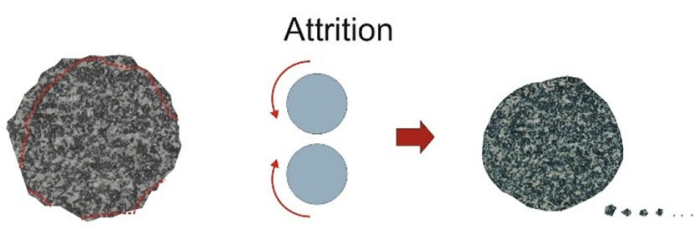

Compression
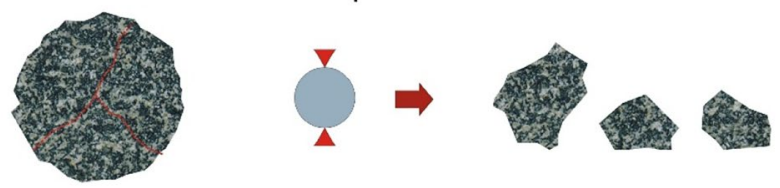

Shearing
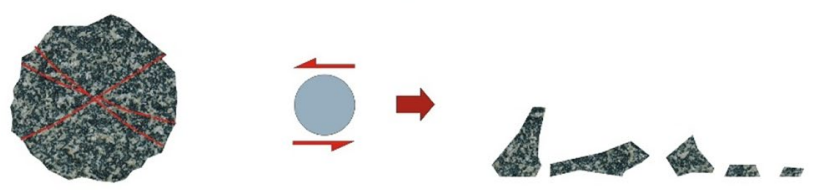

Impact

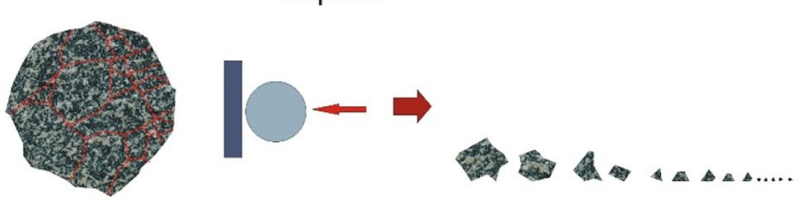

Fig. 4 Various mechanical loads involved in reduction of aggregate particle size during their testing and/or usage (adopted and modified after McNally 1998)

temporal perspective related to depletion of known reserves and geopolitical or social concerns which influence access to certain resources. Specifically in the case of aggregates, social concerns are amongst the most serious factors affecting ability to open a new quarry, specifically in densely populated urban areas. Concerning vulnerability to supply restrictions, the case of constructional aggregates highly differ from the case of, e.g., critical metals. The overall "penetrative" use of aggregates on all inhabited territories, the vulnerability should be discussed more likely on national or even regional level, than on global scale as in the case of metals.

Due to the irreplaceable role of aggregates in construction, their recent and future availability deserves special attention from regional planners (Langer 2002; Dulias 2010; Blachowski 2014). At the same time, perspective areas with high probability of possible opening of a new quarry should be avoided from other uses, specifically from overbuilding (Lopes et al. 2018), as growing cities are considered as one of the main reasons of sterilization of reserves/resources of mineral raw materials in general and specifically in the case of constructional geomaterials (Bronitsky and Wallace 1974b; Poulin et al. 1994; Poulin and Sinding 1996).
The exponentially growing population and urbanization are underlined by soaring consumption of natural resources (Yeh and Huang 2012) from which constructional aggregates constitute the largest part (Bronitsky and Wallace 1974a, b; Campbell and Roberts 2003; Přikryl et al. 2016; Přikryl 2017; Huang et al. 2018). It is well known that urban areas are characterized by much larger volumes of per capita consumption of constructional geomaterials compared to rural ones (Sheridan 1967). However, exploitation of aggregates from geoenvironment is facing major two opposing trends nowadays: (1) still growing demand for aggregates in rapidly expanding and more densely populated urban areas on one hand, and (2) increasing negative attitudes to quarrying/ mining activities which can be sheltered under the NIMBY (i.e., Not In My BackYard) syndrome (Pelekasi et al. 2012). Despite the overall appreciation of resources of construction aggregates as infinite on a global scale, local or regional scarcity of aggregates emerged during last decades in some rapidly developing regions with extremely booming construction activity such as in the Middle East and/or Southeast Asia (Graymore et al. 2008; Ioannidou et al. 2017).

Sustainability of aggregate resources (specifically the primary ones) became intensively discussed during recent decades (Ismail et al. 2013; Danielsen and Kuznetsova 2015; Langer 2016). In general, the sustainability concept of constructional aggregates must reflect their unique role in formulation of major construction materials (such as concrete) on one hand, but also environmental and social responsibilities of mining on the other hand (Langer 2016; Monteiro et al. 2018). Life cycle assessment (LCA) of aggregates including proper management of resources are considered as a key issue in minimizing conflicts between mining companies and society (Danielsen and Kuznetsova 2016).

\section{Conclusions}

Construction aggregates are one of the essential materials supporting the modern construction industry. They are, and will remain, for sure, the most demanded mineral raw material and will keep their top place in near future. It can be expected that the demand for aggregates will grow at least over the next several decades with projected population growth and increasing urbanization, which are two principal factors influencing the demand for infrastructural materials. Importance of aggregates has significantly increased during the twentieth century due to the spread of concrete as the dominant constructional material.

Construction aggregates are raw materials prevalently originating from natural sources-rock masses of various genesis and composition. Properties of aggregates are inevitably linked to their composition, rock fabric and all postgenetic processes that affected them. Understanding of 
aggregate properties (mostly based on the performance in use) should include sound knowledge on their mineralogicalpetrographic composition, which also affects their durability and serviceability.

Construction aggregates are raw materials which do not require too much sophisticated processing scheme: the excavated material is either screened (natural sand and gravel), or crushed and screened (crushed stone) to respective size fractions suitable for final use. The simplicity of processing together with assumed overall availability make them raw materials with lowest intrinsic value at quarry sites. The cost of aggregates is highly sensitive to the transport distance between the site of production and the site of consumption. Higher demand for aggregates are experienced at more densely populated territories; however, the same territories face constraints from inhabitants against mining activities.

Growing world population and rapid urbanization of our recent civilization requires growing inputs of aggregates into the construction industry. Availability of primary resources of sound aggregates or their secondary alternatives (e.g., construction and demolition waste suitable as aggregates) for local construction activities will influence the economy of construction. Environmental concerns related to unwanted impacts of exploitation of primary aggregates (either by blasting / crushing of rock masses or by dredging of natural sands and gravels) increase pressure to use alternative sources of aggregates to sustain the construction industry. However, their usage will require much more detailed investigation in order to minimize economic losses from the application of unsound aggregates.

Funding This study was supported by the Czech Science Foundation project $18-08826 \mathrm{~S}$

\section{References}

Abdelhedi M, Jabbar R, Mnif T, Abbes C (2020) Ultrasonic velocity as a tool for geotechnical parameters prediction within carbonate rocks aggregates. Arab J Geosci 13(4):1-11

Afolagboye LO, Talabi AO, Akinola OO (2016) Evaluation of selected basement complex rocks from Ado-Ekiti, SW Nigeria, as source of road construction aggregates. Bull Eng Geol Environ 75(2):853-865

Afolagboye LO, Talabi AO, Oyelami CA (2017) The use of index tests to determine the mechanical properties of crushed aggregates from Precambrian basement complex rocks, Ado-Ekiti, SW Nigeria. J Afr Earth Sci 129:659-667

Ajalloeian R, Kamani M (2019) An investigation of the relationship between Los Angeles abrasion loss and rock texture for carbonate aggregates. Bull Eng Geol Environ 78(3):1555-1563

Åkesson U, Stigh J, Lindqvist JE, Göransson M (2003) The influence of foliation on the fragility of granitic rocks, image analysis and quantitative microscopy. Eng Geol 68(3):275-288

Akhtar A, Sarmah AK (2018) Construction and demolition waste generation and properties of recycled aggregate concrete: A global perspective. J Clean Prod 186:262-281
Ako TA, Onoduku US, Oke SA, Essien BI, Idris FN, Umar AN, Ahmed AA (2014) Environmental effects of sand and gravel mining on land and soil in Luku, Minna, Niger State. North Central Nigeria J Geosci Geomat 2(2):42-49

Akpokodje EG, Hudec PP (1994) The influence of petrology and fabric on the engineering properties of concretionary laterite gravel aggregates. Q J Eng Geol 27(1):39-50

Alexander M, Mindess S (2005) Aggregates in concrete. Taylor \& Francis, Oxon

Al-Harthi AA (2001) A field index to determine the strength characteristics of crushed aggregate. Bull Eng Geol Environ 60(3): 193-200

Al-Harthi AA, Abo-Saada YE (1997) Wadi natural aggregates in western Saudi Arabia for use in concrete. Bull Int Assoc Eng Geol 55(1):125-135

Al-Harthi AA, Amin AA (1999) Natural aggregates at Makkah governate, western Saudi Arabia. Bull Eng Geol Env 57(4):343-352

Al-Oraimi SK, Taha R, Hassan HF (2006) The effect of the mineralogy of coarse aggregate on the mechanical properties of high-strength concrete. Constr Build Mater 20(7):499-503

Al-Rousan T, Masad E, Tutumluer E, Pan T (2007) Evaluation of image analysis techniques for quantifying aggregate shape characteristics. Constr Build Mater 21(5):978-990

Arasan S, Hasiloglu AS, Akbulut S (2010) Shape properties of natural and crushed aggregate using image analysis. Int J Civ Struct Eng 1(2):221-233

Bahrami S, Aghda SMF, Bahrami K, Rad MM, Poorhashemi S (2015) Effects of weathering and lithology on the quality of aggregates in the alluvial fans of Northeast Rivand, Sabzevar. Iran Geomorphology 241:19-30

Ballivy G, Dayre M (1984) The mechanical behaviour of aggregates related to physicomechanical properties of rocks. Int Assoc Eng Geol Bull 29:339-342

Barakat A, El Baghdadi M, Rais J (2015) A GIS-based inventory of ornamental stone and aggregate operations in the Beni-Mellal region (Morocco). Arab J Sci Eng 40(7):2021-2031

Barakat A, Ouargaf Z, Touhami F (2016) Identification of potential areas hosting aggregate resources using GIS method: a case study of Tadla-Azilal Region. Morocco Environ Earth Sci 75(9):774

Barksdale RD, Kemp MA, Sheffield WJ, Hubbard JL (1991) Measurement of aggregate shape, surface area, and roughness. Transport Res Record 1301:107-116

Barton H (1996) The Isle of Harris Superquarry: concepts of the environment and sustainability. Environ Values 5(2):97-122

Benardos AG, Kaliampakos DC, Prousiotis JG, Mavrikos AA, Skoparantzos KA (2001) Underground aggregate mining in Athens: a promising investment plan. Tunn Undergr Sp Tech 16(4):323-329

Bendixen M, Iversen LL, Best J, Franks DM, Hackney CR, Latrubesse EM, Tusting LS (2021) Sand, gravel, and UN Sustainable Development Goals: conflicts, synergies, and pathways forward. One Earth 4(8):1095-1111

Beushausen H, Dittmer T (2015) The influence of aggregate type on the strength and elastic modulus of high strength concrete. Constr Build Mater 74:132-139

Blachowski J (2014) Spatial analysis of the mining and transport of rock minerals (aggregates) in the context of regional development. Environ Earth Sci 71(3):1327-1338

Black JS (1996) Coastal superquarries in Scotland: planning issues for sustainable development. J Environ Plann Man 39(2):285-294

Bobrowsky PT (1998) Aggregate resources, a global perspective. A.A. Balkema, Rotterdam

Bouquety MN, Descantes Y, Barcelo L, De Larrard F, Clavaud B (2007) Experimental study of crushed aggregate shape. Constr Build Mater 21(4):865-872 
Brattli B (1992) The influence of geological factors on the mechanical properties of basic igneous rocks used as road surface aggregates. Eng Geol 33(1):31-44

Brattli B (1994) The influence of cataclasis on abrasion resistance of granitic rocks used as road surface aggregates. Eng Geol 37(2):149-159

Broekmans MA (2012) Deleterious reactions of aggregate with alkalis in concrete. Rev Mineral Geochem 74(1):279-364

Bronitsky L, Wallace WA (1974a) The impact of urbanization on construction minerals. Omega 2(6):809-813

Bronitsky L, Wallace WA (1974b) The economic impact of urbanization on the mineral aggregate industry. Econ Geogr 50(2):130-140

Brown TJ, Idoine NE, Wrighton CE, Raycraft ER, Hobbs SF, Shaw RA, Everett P, Deady EA, Kresse C (2021) World Mineral Production 2015-19. British Geological Survey, Keyworth, Nottingham, p 89

Brunier G, Anthony EJ, Goichot M, Provansal M, Dussouillez P (2014) Recent morphological changes in the Mekong and Bassac river channels, Mekong delta: the marked impact of river-bed mining and implications for delta destabilisation. Geomorphology 224:177-191

Brzezicki JM, Kasperkiewicz J (1999) Automatic image analysis in evaluation of aggregate shape. J Comput Civ Eng 13(2):123-128

Buruchenko AE, Vereshchagin VI, Men'shikova VK (2020) Lowshrinkage ceramic based on fine-grained dolerite wastes from crushed-stone production. Glass Ceramics 76(11-12):415-418

Bustillo Revuelta M (2021) Construction Materials. Springer, Cham

Campbell GA, Roberts M (2003) Urbanization and mining: a case study of Michigan. Resour Policy 29(1-2):49-60

Capik M, Yilmaz AO (2017) Modeling of micro Deval abrasion loss based on some rock properties J. Afr Earth Sci 134:549-556

Cardoso R, Silva RV, de Brito J, Dhir R (2016) Use of recycled aggregates from construction and demolition waste in geotechnical applications: a literature review. Waste Manag 49:131-145

Cargill JS, Shakoor A (1990) Evaluation of empirical methods for measuring the uniaxial compressive strength of rock. Int J Rock Mech Min Sci Geomech Abstr 27(6):495-503

Çelik T, Marar K (1996) Effects of crushed stone dust on some properties of concrete. Cement Concrete Res 26(7):1121-1130

Cepuritis R, Jacobsen S, Onnela T (2015) Sand production with VSI crushing and air classification: Optimising fines grading for concrete production with micro-proportioning. Mineral Eng 78:1-14

Chandan C, Sivakumar K, Masad E, Fletcher T (2004) Application of imaging techniques to geometry analysis of aggregate particles. J Comput Civ Eng 18(1):75-82

Chen JS, Chang MK, Lin KY (2005) Influence of coarse aggregate shape on the strength of asphalt concrete mixtures. J Eastern Asia Soc Transport Stud 6:1062-1075

Cowell R (2000) Localities and the international trade in aggregates: coastal superquarries on the horizon? Geography 85(2):134-144

Czinder B, Török Á (2017) Long-term durability tests of andesite aggregates from Hungary. Cent Eur Geol 60(3):333-343

Czinder B, Vásárhelyi B, Török Á (2021) Long-term abrasion of rocks assessed by micro-Deval tests and estimation of the abrasion process of rock types based on strength parameters. Eng Geol 282:105996

Danielsen SW, Kuznetsova E (2015) Environmental impact and sustainability in aggregate production and use. In: Lollino G, Giordan D, Marunteanu C, Christaras B, Yoshinori I, Margottini C (eds) Engineering Geology for Society and Territory - vol 5. Urban Geology. Sustainable Planning and Landscape Exploitation. Springer, Cham, pp 41-44

Danielsen SW, Kuznetsova E (2016) Resource management and a best available concept for aggregate sustainability. In: Přikryl R, Török Á, Gómez-Heras M, Miskovsky K, Theodoridou M (eds) Sustainable use of traditional geomaterials in construction practice. Geological Society, London, Special Publications, vol. 416, pp 59-70

De Brito J, Saikia N (2012) Recycled aggregate in concrete: use of industrial, construction and demolition waste. Springer Science \& Business Media, Dordrecht

De Mulder EFJ (1984) A geological approach to traditional and alternative aggregates in the Netherlands. Bull Int Assoc Eng Geol 29(1):49-58

Descantes Y, Hamard E (2015) Parameters influencing the polished stone value (PSV) of road surface aggregates. Constr Build Mater 100:246-254

Diamantis K, Gartzos E, Migiros G (2014) Influence of petrographic characteristics on physico-mechanical properties of ultrabasic rocks from central Greece. Bull Eng Geol Environ 73(4):1273-1292

Đokić O, Motavić V, Erić S, Šarić K (2015) Influence of engineering properties on Polished Stone Value (PSV): a case study on basic igneous rocks from Serbia. Constr Build Mater 101:1088-1096

Drew LJ, Langer WH, Sachs JS (2002) Environmentalism and natural aggregate mining. Nat Resour Res 11(1):19-28

Dulias R (2010) Landscape planning in areas of sand extraction in the Silesian Upland. Poland Landscape Urban Plan 95(3):91-104

Engidasew TA, Barbieri G (2014) Geo-engineering evaluation of Termaber basalt rock mass for crushed stone aggregate and building stone from Central Ethiopia. J Afr Earth Sci 99:581-594

Erdogan ST, Quiroga PN, Fowler DW, Saleh HA, Livingston RA, Garboczi EJ, Ketcham PM, Hagedorn JG, Satterfield SG (2006) Three-dimensional shape analysis of coarse aggregates: New techniques for and preliminary results on several different coarse aggregates and reference rocks. Cement Concrete Res 36(9):1619-1627

Erichsen E (2015) Plotting aggregate degradation results from the Los Angeles test on a triangular diagram: proposal of a new quality ranking for aggregates. Bull Eng Geol Environ 74(2):667-671

Erichsen E, Ulvik A, Sævik K (2011) Mechanical degradation of aggregate by the Los Angeles-, the micro-Deval- and the Nordic test methods. Rock Mech Rock Eng 44(3):333-337

Erskine WD, Geary PM, Outhet DN (1985) Potential impacts of sand and gravel extraction on the Hunter River. New South Wales Austr Geogr Stud 23(1):71-86

Esfahani MK, Kamani M, Ajalloeian R (2019) An investigation of the general relationships between abrasion resistance of aggregates and rock aggregate properties. Bull Eng Geol Environ 78(6):3959-3968

Ferestade I, Hosseini Tehrani P, Heirady R (2017) Fracture toughness estimation of ballast stone used in Iranian railway. J Rock Mech Geotech Eng 9(5):892-899

Fernlund JMR (1998) The effect of particle form on sieve analysis: a test by image analysis. Eng Geol 50(1):111-124

Fernlund JMR (2005a) 3-D image analysis size and shape method applied to the evaluation of the Los Angeles test. Eng Geol 77(1-2):57-67

Fernlund JMR (2005b) Image analysis method for determining 3-D shape of coarse aggregate. Cement Concrete Res 35(8):1629-1637

Fernlund JMR (2005c) Image analysis method for determining 3-D size distribution of coarse aggregates. Bull Eng Geol Environ 64(2):159-166

Fernlund JM, Zimmerman RW, Kragic D (2007) Influence of volume/ mass on grain-size curves and conversion of image-analysis size to sieve size. Eng Geol 90(3):124-137

Fookes PG (1980) An introduction to the influence of natural aggregates on the performance and durability of concrete. Q J Eng Geol 13(4):207-229

Fookes PG (1991) Geomaterials. Q J Eng Geol 24(1):3-15 
Fookes PG (1997) Aggregates: a review of prediction and performance. In: Glanville J, Neville A (eds) Prediction of Concrete Durability: Proceedings of STATS 21st Anniversary Conference. E \& FN Spon, London, p 91-170

Fookes PG, Walker MJ (2011) Natural aggregates in the performance and durability of concrete: physical characteristics. Geol Today 27(4):141-148

Fookes PG, Walker MJ (2012) Natural aggregates in the performance and durability of concrete: chemical characteristics. Geol Today 28(1):20-25

Fournier B, Bérubé MA (2000) Alkali-aggregate reaction in concrete: a review of basic concepts and engineering implications. Can J Civil Eng 27(2):167-191

French WJ (1991) Concrete petrography: a review. Q J Eng Geol Hydrogeol 24(1):17-48

Fry M (2011) From crops to concrete: Urbanization, deagriculturalization, and construction material mining in Central Mexico. Ann Assoc Am Geogr 101(6):1285-1306

Gagg CR (2014) Cement and concrete as an engineering material: An historic appraisal and case study analysis. Eng Fail Anal 40:114-140

Ganapati N, Adiseshu PS (2013) Influence of coarse aggregate shape factors on bituminous mixtures. Int J Eng Res Applic 1(4):2013-2024

Garboczi EJ (2002) Three-dimensional mathematical analysis of particle shape using X-ray tomography and spherical harmonics: Application to aggregates used in concrete. Cement Concrete Res 32(10):1621-1638

Gavriletea MD (2017) Environmental impacts of sand exploitation. Analysis of Sand Market Sustainability 7:1118

Goswami SC (1984a) Quarrying of aggregates in and around Gauhati: impact on the environment. Bull Int Assoc Eng Geol 29(1):265-268

Goswami SC (1984b) Influence of geological factors on soundness and abrasion resistance of road surface aggregates: A case study. Bull Int Assoc Eng Geol 30(1):59-61

Graedel TE, Barr R, Chandler C, Chase T, Choi J, Christoffersen L, Friedlander E, Henly C, Jun C, Nassar NT, Schechner D, Warren S, Yang MY, Zhu C (2012) Methodology of metal criticality determination. Environ Sci Technol 46(2):1063-1070

Graymore MLM, Sipe NG, Rickson RE (2008) Regional sustainability: how useful are current tools of sustainability assessment at the regional scale? Ecol Econ 67(3):362-372

Guimaraes MS, Valdes JR, Palomino AM, Santamarina JC (2007) Aggregate production: fines generation during rock crushing. Int J Miner Process 81(4):237-247

Guo Y, Markine V, Song J, Jing G (2018) Ballast degradation: effect of particle size and shape using Los Angeles Abrasion test and image analysis. Constr Build Mater 169:414-424

Hamad BS, Yassine MY, Khawlie MR (1996) A survey study on geology and location of major sand resources in Lebanon, eastern Mediterranean. Bull Int Assoc Eng Geol 53(1):39-48

Hamad BS, Khoury GR, Khawlie MR (2000) Geology and location of major coarse aggregate resources in Lebanon. Eastern Mediterranean Bull Eng Geol Environ 58(3):183-190

Hameed MS, Sekar ASS (2009) Properties of green concrete containing quarry rock dust and marble sludge powder as fine aggregate. ARPN J Eng Appl Sci 4(4):83-89

Hartley A (1974) A review of the geological factors influencing the mechanical properties of road surface aggregates. Q J Eng Geol 7(1):69-100

Hasdemir S, Tuğrul A, Yılmaz M (2016) The effect of natural sand composition on concrete strength. Constr Build Mater 112:940-948
Hofer V, Bach H, Latal C, Neubauer AC (2013) Impact of geometric and petrographic characteristics on the variability of LA test values for railway ballast. Math Geosci 45:727-752

Hofmann M, Büchi A, Hoppe A, Hornung J, Karfunkel J, Pagung $\mathrm{R}$ (2009) Resources for a growing city-sand extraction north of Belo Horizonte (Brazil). Neues Jahrb Geol Palaontol Abh 253(1):61-78

Horvath A (2004) Construction materials and the environment. Ann Rev Environ Resour 29:181-204

Huang Y, Bird RN, Heidrich O (2007) A review of the use of recycled solid waste materials in asphalt pavements. Resour Conserv Recyc 52(1):58-73

Huang W, Huang Y, Lin S, Chen Z, Gao B, Cui S (2018) Changing urban cement metabolism under rapid urbanization-A flow and stock perspective. J Clean Prod 173:197-206

Indraratna B, Salim W, Rujikiatkamjorn C (2011) Advanced rail geotechnology-ballasted track. CRC Press, Boca Raton

Ingham JP (2009) Application of petrographic examination techniques to the assessment of fire-damaged concrete and masonry structures. Mater Charact 60(7):700-709

Ingham JP (2011) Petrography of geomaterials: a review. Q J Eng Geol Hydrogeol 44(4):457-467

Ingham J (2019) Geomaterials under the microscope: a colour guide. CRC Press, Boca Raton

Ioannidou D, Meylan G, Sonnemann G, Habert G (2017) Is gravel becoming scarce? Evaluating the local criticality of construction aggregates. Resour Conserv Recy 126:25-33

Irfan TY (1994) Aggregate properties and resources of granitic rocks for use in concrete in Hong Kong. Q J Eng Geol 27:25-28

Ismail S, Hoe KW, Ramli M (2013) Sustainable aggregates: The potential and challenge for natural resources conservation. Procedia Soc Behav Sci 101:100-109

Jadhav PA, Kulkarni DK (2013) Effect of replacement of natural sand by manufactured sand on the properties of cement mortar. Int J Civ Structur Eng 3(3):621-628

Jamil MZ, Khan MS (2014) Establishment of correlation between Los Angeles abrasion loss and strength determined through point load index and Schmidt rebound hammer. Sci Inter 26(2):767-770

Jin Y, Kim J, Guillaume B (2016) Review of critical material studies. Resour Conserv Recy 113:77-87

Johansson E, Miskovsky K, Loorents KJ (2009) Estimation of rock aggregates quality using analyses of drill cuttings. J Mater Eng Perform 18(3):299-304

Kabir S, Al-Shayeb A, Khan IM (2016) Recycled construction debris as concrete aggregate for sustainable construction materials. Procedia Eng 145:1518-1525

Kahraman S, Fener M (2007) Predicting the Los Angeles abrasion loss of rock aggregates from the uniaxial compressive strength. Mater Lett 61(26):4861-4865

Kahraman S, Fener M (2008) Electrical resistivity measurements to predict abrasion resistance of rock aggregates. Bull Mater Sci 31(2):179-184

Kahraman S, Gunaydin O (2007) Empirical methods to predict the abrasion resistance of rock aggregates. Bull Eng Geol Environ 66(4):449-455

Kahraman S, Toraman OY (2008) Predicting Los Angeles abrasion loss of rock aggregates from crushability index. Bull Mater Sci 31(2): 173-177

Karakaş A (2014) Defining the suitability of new crushed rock aggregate source areas in the North of Kocaeli Province using GIS Bull Eng Geol Environ 73(4):1183-1197

Kasim M, Shakoor A (1996) An investigation of the relationship between uniaxial compressive strength and degradation for selected rock types. Eng Geol 44(1-4):213-227 
Kazi A, Al-Mansour ZR (1980a) Empirical relationship between Los Angeles abrasion and Schmidt hammer strength tests with application to aggregate around Jeddah. Q J Eng Geol 13(1):45-52

Kazi A, Al-Mansour ZR (1980b) Influence of geological factors on abrasion and soundness characteristics of aggregates. Eng Geol 15(3-4):195-203

Kecojevic V, Nelson T, Schissler A (2004) An analysis of aggregates production in the United States: historical data and issues facing the industry. Miner Energy-Raw Mate Rep 19(4):25-33

Kılıç A, Atiş CD, Teymen A, Karahan O, Özcan F, Bilim C, Özdemir $M$ (2008) The influence of aggregate type on the strength and abrasion resistance of high strength concrete. Cement Concrete Comp 30(4):290-296

Kirthika SK, Singh SK, Chourasia A (2020) Alternative fine aggregates in production of sustainable concrete-a review. J Clean Prod 268:122089

Korkanç M, Tuğrul A (2004) Evaluation of selected basalts from Niğde, Turkey, as source of concrete aggregate. Eng Geol 75(3-4):291-307

Koukis G, Sabatakakis N, Spyropoulos A (2007) Resistance variation of low-quality aggregates. Bull Eng Geol Environ 66(4):457-466

Krutilová K, Přrikryl R (2017) Relationship between Polished Stone Value (PSV) and Nordic abrasion value (AN) of volcanic rocks. Bull Eng Geol Environ 76(1):85-99

Kühnel RA, Van der Gaast SJ, Brych J, Laan GJ, Kulnig H (1994) The role of clay minerals in durability of rocks observations on basaltic rocks. App Clay Sci 9(4):225-237

Langer WH (1988) Natural aggregates of the conterminous United States. US Geological Survey Bulletin 1594, Washington

Langer WH (1995) Geologic and societal factors affecting the international oceanic transport of aggregate. Nonrenew Resour 4(4):303-309

Langer WH (2002) Managing and protecting aggregate resources. U.S. Department of the Interior, U.S. Geological Survey. Denver, Open-File Report 02-415

Langer W (2016) Sustainability of aggregates in construction. In: Khatib JM (ed) Sustainability of Construction Materials. Woodhead Publishing, Duxford, pp 181-207

Langer WH, Lindsey DA, Knepper DH (2002) Geologic information for aggregate resource planning. In: Fabbri AG, Gaál G, McCammon RB (eds) Deposit and Geoenvironmental Models for Resource Exploitation and Environmental Security. Springer, Dordrecht, pp 135-149

Lee CF, White OL (1993) Engineering geology in underground aggregate mining and space utilisation. Eng Geol 35(3-4):247-257

Lees G (1964) The measurement of particle shape and its influence in engineering materials. J Brit Granite Whinstone Fed 4:1-22

Lees G, Kennedy CK (1975) Quality, shape and degradation of aggregates. Q J Eng Geol 8(3):193-209

Li L, Chan P, Zollinger DG, Lytton RL (1993) Quantitative analysis of aggregate shape based on fractals. ACI Mater J 90(4):357-365

Lindgård J, Andiç-Çakır Ö, Fernandes I, Rønning TF, Thomas MD (2012) Alkali-silica reactions (ASR): Literature review on parameters influencing laboratory performance testing. Cem Concr Res 42(2):223-243

Loorents KJ, Kondelchuk D (2009) Trends of enrichment of free mica grains in crushed rock aggregates. Bull Eng Geol Environ 68(1):89-96

Loorents KJ, Johansson E, Arvidsson H (2007) Free mica grains in crushed rock aggregates. Bull Eng Geol Environ 66(4):441-447

Lopes C, Lisboa V, Carvalho J, Mateus A, Martins L (2018) Challenges to access and safeguard mineral resources for society: a case study of kaolin in Portugal. Land Use Policy 79:263-284
Lorenz W, Gwosdz W (2003) Manual on the geological-technical assessment of mineral construction materials. Geologisches Jahrbuch SH 15:1-498

Maerz NH (2004) Technical and computational aspects of the measurement of aggregate shape by digital image analysis. J Comput Civil Eng 18(1):10-18

Malešev M, Radonjanin V, Marinković S (2010) Recycled concrete as aggregate for structural concrete production. Sustainability 2(5):1204-1225

Maltz A (1994) Commentary on the Harris Superquarry Inquiry. J Law Relig 11(2):793-833

Manasseh JOEL (2010) Use of crushed granite fine as replacement to river sand in concrete production. Leonardo Electron J Pract Technol 17:85-96

Manguriu GN, Karugu CK, Oyawa WO, Abuodha SO, Mulu PU (2013) Partial replacement of natural river sand with crushed rock sand in concrete production. Glob Eng Technol Rev 3(4):7-14

Masad E, Button J, Papagiannakis T (2000) Fine-aggregate angularity: automated image analysis approach. Transport Res Record 1721:66-72

Masad E, Saadeh S, Al-Rousan T, Garboczi E, Little D (2005) Computations of particle surface characteristics using optical and X-ray CT images. Comput Mater Sci 34(4):406-424

McNally GH (1998) Soil and rock construction materials. E \& FN Spon, London

Mehta PK (2002) Greening of the concrete industry for sustainable development. Concr Int 24(7):23-28

Menegaki ME, Kaliampakos DC (2010) European aggregates production: Drivers, correlations and trends. Resour Policy 35(3):235-244

Meyer C (2009) The greening of the concrete industry. Cem Concr Comp 31(8):601-605

Miatto A, Schandl H, Fishman T, Tanikawa H (2017) Global patterns and trends for non-metallic minerals used for construction. J Ind Ecol 21(4):924-937

Millar DL, Brown TJ, Kruyswijk JB, Smith N, Coggan JS, Foster PJ, Steadman EJ, Evans DJ, Hewitt J (2012) Assessing the feasibility of underground mining of aggregates in southern and eastern England. In: Hunger E, Walton G (eds) Proceedings of the 16th Extractive Industry Geology Conference. EIG Conferences Ltd., Portsmouth, pp 54-70

Miskovsky K (2004) Enrichment of fine mica originating from rock aggregate production and its influence on the mechanical properties of bituminous mixtures. J Mater Eng Perform 13(5):607-611

Miskovsky K, Duarte MT, Kou SQ, Lindqvist PA (2004) Influence of the mineralogical composition and textural properties on the quality of coarse aggregates. J Mater Eng Perform 13(2):144-150

Monteiro NBR, Moita Neto JM, da Silva EA (2018) Bibliometric study of the crushed stone mining sector. Min Proc Ext Met Rev 39(4):235-249

Mora CF, Kwan AKH (2000) Sphericity, shape factor, and convexity measurement of coarse aggregate for concrete using digital image processing. Cement Concrete Res 30(3):351-358

Mora CF, Kwan AKH, Chan HC (1998) Particle size distribution analysis of coarse aggregate using digital image processing. Cement Concrete Res 28(6):921-932

Mundra S, Sindhi PR, Chandwani V, Nagar R, Agrawal V (2016) Crushed rock sand-An economical and ecological alternative to natural sand to optimize concrete mix. Perspect Sci 8:345-347

Naeem M, Khalid P, Sanaullah M, ud Din Z (2014) Physio-mechanical and aggregate properties of limestones from Pakistan. Acta Geod Geophys 49(3):369-380

Nurmikolu A (2012) Key aspects on the behaviour of the ballast and substructure of a modern railway track: research-based practical observations in Finland. J Zhejiang Univ Sc A 13(11):825-835 
O’Brien J (2016) Global aggregates industry under the spotlight. Mod Quarry 2016:15-16

Oikonomou ND (2005) Recycled Concrete Aggregates Cement Concrete Comp 27(2):315-318

Ozcelik Y (2011) Prediction Los Angeles abrasion of rocks from some physical and mechanical properties. Sci Res Essays 6(7):1612-1619

Padmalal D, Maya K, Sreebha S, Sreeja R (2008) Environmental effects of river sand mining: a case from the river catchments of Vembanad lake. Southwest Coast of India Environ Geol 54(4):879-889

Paige-Green P (2007) Durability testing of basic crystalline rocks and specification for use as road base aggregate. Bull Eng Geol Environ 66(4):431-440

Palassi M, Danesh A (2015) Relationships between abrasion/degradation of aggregate, evaluated from various tests and the effect of saturation. Rock Mech Rock Eng 49(7):2937-2943

Pelekasi T, Menegaki M, Damigos D (2012) Externalities, NIMBY syndrome and marble quarrying activity. J Environ Plann Man 55(9):1192-1205

Persson AL (1998) Image analysis of shape and size of fine aggregates. Eng Geol 50(1):177-186

Persson L, Göransson M (2005) Mechanical quality of bedrock with increasing ductile deformation. Eng Geol 81(1):42-53

Pomonis P, Rigopoulos I, Tsikouras B, Hatzipanagiotou K (2007) Relationships between petrographic and physicomechanical properties of basic igneous rocks from the Pindos ophiolitic complex. NW Greece Bull Geol Soc Greece 40(2):947-958

Poole AB, Sims I (2016) Concrete petrography: a handbook of investigative techniques. CRC Press, Boca Raton

Poulin R, Sinding K (1996) A North American perspective on land use and mineral aggregate production. GeoJournal 40(3):273-281

Poulin R, Pakalnis RC, Sinding K (1994) Aggregate resources: production and environmental constraints. Environ Geol 23(3):221-227

Prentice JE (1990) Geology of construction materials. Chapman and Hall, London

Pries F, Janszen F (1995) Innovation in the construction industry: the dominant role of the environment. Constr Manag Econ 13(1):43-51

Primel L, Tourenq C (2000) Aggregates. A.A. Balkema, Rotterdam

Přikryl R (2001) Some microstructural aspects of strength variation in rocks. Int J Rock Mech Min Sci Geomech Abstr 38(5):671-682

Přikryl R (2006) Assessment of rock geomechanical quality by quantitative rock fabric coefficients: Limitations and possible source of misinterpretations. Eng Geol 87(3-4):149-162

Přikryl R (2013) Durability assessment of natural stone. Q J Eng Geol Hydrogeol 46(4):377-390

Přikryl R (2017) Constructional geomaterials: versatile earth resources in the service of humankind-introduction to the thematic set of papers on: challenges to supply and quality of geomaterials used in construction. Bull Eng Geol Environ 76(1):1-9

Přikryl R, Török Á, Theodoridou M, Gomez-Heras M, Miskovsky K (2016) Geomaterials in construction and their sustainability: understanding their role in modern society. In: Přikryl R, Török Á, Gómez-Heras M, Miskovsky K, Theodoridou M (eds) Sustainable use of traditional geomaterials in construction practice. Geological Society, London, Special Publications, vol. 416, pp 1-22

Profitis E, Chatzitheodoridis E, Xirouchakis D (2012) Digital methods for flakiness and shape definition. In: Paipetis AS, Matikas TE, Aggelis DG, Van Hemelriijck D (eds) Emerging technologies in non-destructive testing V. CRC Press, London, pp 437-440

Räisänen M, Mertamo M (2004) An evaluation of the procedure and results of laboratory crushing in quality assessment of rock aggregate raw materials. Bull Eng Geol Env 63(1):33-39

Räisänen M, Torppa A (2005) Quality assessment of a geologically heterogeneous rock quarry in Pirkanmaa county, southern Finland. Bull Eng Geol Environ 64(4):409-418
Räisänen M, Kupiainen K, Tervahattu H (2003) The effect of mineralogy, texture and mechanical properties of anti-skid and asphalt aggregates on urban dust. Bull Eng Geol Environ 62(4):359-368

Räisänen M, Kupiainen K, Tervahattu H (2005) The effect of mineralogy, texture and mechanical properties of anti-skid and asphalt aggregates on urban dust, stages II and III. Bull Eng Geol Environ 64(3):247-256

Ramsay DM (1965) Factors influencing aggregate impact value in rock aggregate. Quarry Manager J 49:129-134

Ramsay DM, Dhir RK, Spence JM (1974) The role of rock and clast fabric in the physical performance of crushed-rock aggregate. Eng Geol 8(3):267-285

Ramsay DM, Dhir RK, Spence JM (1977) The practical and theoretical merits of the aggregate impact value in the study of crushed rock aggregate. In: Attewell PB (ed) Proceedings of the Conference on Rock Engineering, University of Newcastle-uponTyne. British Geotechnical Society, London, pp 1-10

Rao GA, Prasad BR (2004) Influence of type of aggregate and surface roughness on the interface fracture properties. Mater Struct 37(5):328-334

Rao C, Tutumluer E, Kim IT (2002) Quantification of coarse aggregate angularity based on image analysis. Transport Res Record 1787:117-124

Rigopoulos I, Tsikouras B, Pomonis P, Hatzipanagiotou K (2010) The influence of alteration on the engineering properties of dolerites: the examples from the Pindos and Vourinos ophiolites (northern Greece). Int J Rock Mech Min Sci 47(1):69-80

Rigopoulos I, Tsikouras B, Pomonis P, Hatzipanagiotou K (2012) The impact of petrographic characteristics on the engineering properties of ultrabasic rocks from northern and central Greece. Q J Eng Geol Hydrogeol 45(4):423-433

Rigopoulos I, Tsikoura B, Pomonis P, Hatzipanagiotou K (2013) Determination of the interrelations between the engineering parameters of construction aggregates from ophiolite complexes of Greece using factor analysis. Constr Build Mater 49:747-757

Rigopoulos I, Tsikouras B, Pomonis P, Hatzipanagiotou K (2014) Correlations between petrographic and geometrical properties of ophiolitic aggregates from Greece. Bull Eng Geol Environ 73(1):1-12

Rigopoulos I, Török Á, Kyratsi T, Delimitis A, Ioannou I (2018) Sustainable exploitation of mafic rock quarry waste for carbon sequestration following ball milling. Resour Pol 59:24-32

Robinson GR Jr, Kapo KE (2004) A GIS analysis of suitability for construction aggregate recycling sites using regional transportation network and population density features. Resour Conserv Recy 42(4):351-365

Robinson GR, Larkins PM (2007) Probabilistic prediction models for aggregate quarry siting. Nat Resour Res 16(2):135-146

Robinson GR, Kapo KE, Raines GL (2004) A GIS analysis to evaluate areas suitable for crushed stone aggregate quarries in New England, USA. Nat Resour Res 13(3):143-159

Rosenau-Tornow D, Buchholz P, Riemann A, Wagner M (2009) Assessing the long-term supply risks for mineral raw materialsa combined evaluation of past and future trends. Resour Policy 34:161-175

Schandl H, West J (2010) Resource use and resource efficiency in the Asia-Pacific region. Global Environ Change 20(4):636-647

Schandl H, West J (2012) Material flows and material productivity in China, Australia, and Japan. J Ind Ecol 16(3):352-364

Shakoor A, Brown CL (1996) Development of a quantitative relationship between unconfined compressive strength and Los Angeles abrasion loss for carbonate rocks. Bull Int Assoc Eng Geol 53(1):97-103

Shakoor A, West TR, Scholer CF (1982) Physical characteristics of some Indiana argillaceous carbonates regarding their freeze-thaw resistance in concrete. Bull Int Assoc Eng Geol 19(4):371-384 
Sheridan MJ (1967) Urbanization and Its Impact on the Mineral Aggregate Industry in the Denver, Colo., Area. Information Circular 8320, U.S. Department of the Interiors, Bureau of Mines, Washington

Silva RV, De Brito J, Dhir RK (2014) Properties and composition of recycled aggregates from construction and demolition waste suitable for concrete production. Constr Build Mater 65:201-217

Smith MR, Collis L (2001) Aggregates. Sand, gravel and crushed rock aggregates for construction purposes, 3rd edn. Geological Society, London, Engineering Geology Special Publications, p 17

Solís-Guzmán J, Marrero M (2015) Ecological footprint assessment of building construction. Bentham Science Publishers, Berlin

Sonebi M, Ammar Y, Diederich P (2016) Sustainability of cement, concrete and cement replacement materials in construction. In: Khatib JM (ed) Sustainability of Construction Materials. Woodhead Publishing, Duxford, pp 371-396

Stocks J (1979) The production of aggregates by underground mining methods-development of a simulation technique for prefeasibility analysis. Miner Environ 1(4):148-160

Stubbs BJ, Smith JV (1997) Weathered bedrock as a source of sand and gravel aggregate in north-eastern New South Wales. Australia Environ Geol 32(1):64-70

Tam VW, Soomro M, Evangelista ACJ (2018) A review of recycled aggregate in concrete applications (2000-2017). Constr Build Mater 172:272-292

Teymen A (2019) Estimation of Los Angeles abrasion resistance of igneous rocks from mechanical aggregate properties. Bull Eng Geol Environ 78(2):837-846

Török Á (2015) Los Angeles and micro-Deval values of volcanic rocks and their use as aggregates, examples from Hungary. In: Lollino G, Manconi A, Guzzetti F, Culshaw M, Bobrowsky P, Luino F (eds) Engineering geology for society and territory, vol 5. Urban geology, sustainable planning and landscape exploitation. Springer, Cham, pp 115-118

Török Á, Czinder B (2017) Relationship between density, compressive strength, tensile strength and aggregate properties of andesites from Hungary. Environ Earth Sci 76(18):1-14

Torres A, Simoni MU, Keiding JK, Müller DB, zu Ermgassen SOSE, Liu J, Jaeger JAG, Winter M, Lambin EF (2021) Sustainability of the global sand system in the Anthropocene. One Earth 4(5):639-650

Tuğrul A, Y1lmaz M (2012) Assessing the quality of sandstones for use as aggregate in concrete. Mag Concr Res 64(12):1067-1078

Tuğrul A, Zarif IH (1999) Correlation of mineralogical and textural characteristics with engineering properties of selected granitic rocks from Turkey. Eng Geol 51(4):303-317

Tuğrul A, Yilmaz M, Sönmez İ, Hasdemir S (2016) Sustainable management of aggregate resources in İstanbul. In: Eggers MJ, Griffiths JS, Parry S, Culshaw MG (eds) Developments in Engineering Geology. Engineering Geology Special Publications vol. 27, Geological Society, London, pp 55-61
Tuncay EB, Kilinçarslan Ş, Yağmurlu F (2016) Investigation of usability as aggregate of different originated rocks. IOP Conference Series: Earth Environ Sci 44(2):022002

Turk N, Dearman WR (1988) An investigation into the influence of size on the mechanical properties of aggregates. Bull Int Assoc Eng Geol 38(1):143-149

Ugur I, Demirdag S, Yavuz H (2010) Effect of rock properties on the Los Angeles abrasion and impact test characteristics of the aggregates. Mater Charact 61(1):90-96

Ündül Ö, Tuğrul A (2012) The influence of weathering on the engineering properties of dunites. Rock Mech Rock Eng 45(2):225-239

U.S. Geological Survey (2021) Mineral commodity summaries 2021. U.S. Geological Survey, p 200. https://doi.org/10.3133/mcs2021

Uthus L, Tutumluer E, Horvli I, Hoff I (2007) Influence of grain shape and surface texture on the deformation properties of unbound aggregates in pavements. Int J Pavements 6(1):75-87

van Loon AJ (2002) The complexity of simple geology. Earth Sci Rev 59(1-4):287-295

Verhoef PN, Van de Wall AR (1998) Application of petrography in durability assessment of rock construction materials. In: Bobrowsky PT (ed) Aggregate resources, a global perspective. A.A. Balkema, Rotterdam, p 307-330

Vignaroli G, Belardi G, Serracino M (2013) Multi-scale geological evaluation for quarrying activities in ophiolitic rocks: implications for asbestos-related legislation. Bull Eng Geol Environ 72(3-4):285-302

Vignaroli G, Urru G, Rossetti F, Belardi G, Piaggi L (2017) Tectonic structures and commercial compartments in active quarrying: a case history from northern Italy. Bull Eng Geol Environ 76(2):477-496

Wang W (1999) Image analysis of aggregates. Comput Geosci 25(1):71-81

West G (1994) Estimating aggregate properties from the unconfined compressive strength of rock. Q J Eng Geol 27(3):275-276

Westerholm M, Lagerblad B, Silfwerbrand J, Forssberg E (2008) Influence of fine aggregate characteristics on the rheological properties of mortars. Cement Concrete Comp 30(4):274-282

Wilburn DR, Goonan TG (1998) Aggregates from natural and recycled sources. Economic Assessments for Construction ApplicationsA Materials Flow Analysis. U.S. Geological Survey Circular 1176, U.S. Department of the Interiors, Denver

Xirouchakis D (2013) Correlations between mechanical and geometrical parameters in aggregates: a tool for quality assessment and control. Bull Geol Soc Greece 47(3):2069-2080

Yeh CT, Huang SL (2012) Global urbanization and demand for natural resources. In: Lal R, Augustin B (eds) Carbon Sequestration in Urban Ecosystems. Springer, Dordrecht, pp 355-371

Zhang X, Zhao C, Zhai W, Shi C, Feng Y (2019) Investigation of track settlement and ballast degradation in the high-speed railway using a full-scale laboratory test. P I Mech Eng F-J Rai 233(8):869-881 